\title{
Large spatial variation and female bias in the estimated sex ratio of loggerhead sea turtle hatchlings of a Mediterranean rookery
}

\author{
Judith A. Zbinden ${ }^{1, *}$, Christina Davy ${ }^{2}$, Dimitris Margaritoulis ${ }^{3}$, Raphaël Arlettaz ${ }^{1}$ \\ ${ }^{1}$ Zoological Institute, Division of Conservation Biology, Baltzerstrasse 6, 3012 Bern, Switzerland \\ ${ }^{2}$ Department of Biology, University of Western Ontario, London, Ontario N6A 5B7, Canada \\ ${ }^{3}$ ARCHELON, The Sea Turtle Protection Society of Greece, Solomou 57, 10432 Athens, Greece
}

\begin{abstract}
Adult sex ratio is a crucial parameter in population dynamics, with environmental sex determination being of particularly high theoretical and conservation interest. Monitoring hatchling sex ratio over time and space and understanding its variation may prove essential for effective conservation of populations of species with temperature-dependent sex determination. We used clutch incubation duration to estimate sex ratio of hatchlings produced on Zakynthos (Greece), the largest rookery of loggerhead sea turtles Caretta caretta (a species with temperature-dependent sex determination: colder temperatures producing more males) in the Mediterranean. We also explored spatial variation in hatchling sex ratio estimates within this nesting area. The estimated hatchling sex ratio on Zakynthos was female-biased in 2002 and 2003 (68 and 75\% females estimated, respectively). We found significant differences in incubation durations between the 6 nesting beaches of Zakynthos, which result in pronounced differences in estimated hatchling sex ratio. Little is known about the relationship between adult and hatchling sex ratio or about the minimum number of males needed in healthy sea turtle populations. With global climate change, however, particular attention should be paid to the protection of the beaches that are apparently characterised by comparatively cold incubation temperatures to provide females with a variety of incubation environments.
\end{abstract}

KEY WORDS: Caretta caretta - Incubation duration - Loggerhead sea turtle - Mediterranean . Temperature-dependent sex determination

\section{INTRODUCTION}

Adult sex ratio is a crucial demographic parameter affecting the viability of vertebrate populations. It figures amongst the determining factors in calculations of both demographic and genetic effective population sizes (Caughley \& Gunn 1996). Theory predicts that the evolutionarily stable primary sex ratio should be unbiased except under certain conditions (for example, if parental investment is not equal for both sexes, if brothers compete for mates or if offspring of one sex help the parents; Fisher 1930). Sex determination in most vertebrate species is genotypic, leaving little scope for deviations from a balanced primary sex ratio.
On the contrary, in many turtle, some lizard and all crocodilian species, gender is determined by the prevailing environmental conditions (mainly temperature) during embryonic development. Environmental sex determination leaves ample scope for variation in primary sex ratio, but should theoretically be subject to the same evolutionary constraint leading to balanced primary sex ratios as genotypic sex determination. However, although none of the conditions for predicted unbalanced primary sex ratios apply, consistently female-biased hatchling sex ratios (which can be assumed to be similar to primary sex ratios) are reported from different taxa with environmental sex determination, for example freshwater turtles (Vogt \& 
Bull 1984), sea turtles (Wibbels 2003) and crocodiles (Hutton 1987). Such female-skewed hatchling sex ratios are considered to be more common than balanced or male-skewed primary sex ratios (Freedberg \& Wade 2001, Wibbels 2003), at least for sea turtles, the group for which most data exist. Although there have been theoretical mechanisms proposed to explain female-skewed primary sex ratios in populations of species with environmental sex determination in the framework of evolutionary theory (Bull \& Charnov 1989, Freedberg \& Wade 2001), it remains unclear whether these act in populations. Environmental sex determination thus remains a highly challenging topic in evolutionary biology. Moreover, temperature-dependent sex determination is of high topicality in conservation biology (e.g. Girondot et al. 1998). Especially in small populations, change in availability of specific incubation habitat may lead to detrimental shifts in sex ratios. Additionally, global climate change (Houghton et al. 2001) may lead to changes in hatchling sex ratios. Monitoring hatchling sex ratio over time and space and understanding its variation may therefore prove essential for efficient protection of populations of species with temperature-dependent sex determination.

In sea turtles, sex is determined by the temperature during the middle third of incubation, with warmer temperatures producing a higher proportion of females and colder temperatures resulting in a higher proportion of males either side of the pivotal temperature, which produces $50 \%$ of either sex (Mrosovsky \& Pieau 1991). In a Mediterranean loggerhead sea turtle rookery, for example, the pivotal temperature was determined to be $29.3^{\circ} \mathrm{C}$, with the range between all maleand all female-producing temperatures being about $1.5^{\circ} \mathrm{C}$ (Mrosovsky et al. 2002).

This study focuses on hatchling sex ratio in Mediterranean loggerhead sea turtles Caretta caretta, which are demographically independent from Atlantic populations (Bowen et al. 1993, Laurent et al. 1993, Carreras et al. 2007). The Mediterranean aggregation is of a relatively small size comprising approximately 5000 clutches annually (Margaritoulis et al. 2003), and is heavily affected by fishery bycatch (Gerosa \& Casale 1999, Lewison et al. 2004). It is therefore of special conservation concern. Within the Mediterranean, the island of Zakynthos hosts the largest known rookery of loggerhead sea turtles, accounting for roughly a quarter of all recorded clutches with an average of ca. 1300 clutches laid annually (Margaritoulis et al. 2003). The nesting area on Zakynthos consists of 6 distinct adjacent beaches (Fig. 1a), which differ in physical characteristics (for example, sand grain size and aspect), raising the possibility that sand temperature and, accordingly, hatchling sex ratio may differ amongst beaches. Our aims were to (1) estimate hatchling sex ratio in Zakynthos and (2) investigate spatial variation in hatchling sex ratio by exploring the hypothesis that the individual beaches differ in hatchling sex ratios produced.

Since the sex of sea turtle hatchlings cannot be assessed from external morphology and scarifying hatchlings was not an option from an ethical and conservation perspective, we used incubation duration of clutches as an indirect method to estimate hatchling sex ratio. The incubation duration is strongly determined by incubation temperature (Ackerman 1997). The validity of using incubation durations as a proxy of incubation temperatures has been confirmed by histological sexing of hatchlings from clutches with known incubation duration (Godfrey \& Mrosovsky 1997, Mrosovsky et al. 1999).

\section{MATERIALS AND METHODS}

Study area. The island of Zakynthos $\left(37^{\circ} 38^{\prime}-\right.$ $37^{\circ} 56^{\prime} \mathrm{N}, 20^{\circ} 37^{\prime}-21^{\circ} \mathrm{E}$ ) is situated in the Ionian Sea in the eastern Mediterranean (Fig. 1a). The climate is highly seasonal with relatively high temperatures and generally little rainfall in summer, while autumn and winter are characterised by lower temperatures, heavy rains and storms.

Incubation duration data. We collected data on incubation duration of loggerhead sea turtle clutches during 2002 and 2003 within the ARCHELON (The Sea Turtle Protection Society of Greece) long-term monitoring project described by Margaritoulis (2005). Incubation duration was defined as the number of days from the date a clutch was laid to the date of first hatchling emergence - because a large proportion of the hatchlings of a given clutch usually emerge during the first night on Zakynthos (ARCHELON unpubl. data), considering the date of emergence of the first hatchlings of a clutch as the emergence date for the entire clutch only slightly underestimates average incubation durations. Both nesting and hatching emergence normally occur at night. They were systematically determined from observation of tracks during early morning patrols, and the date of these events was consistently recorded as the morning after the event took place. Patrols always started at one end of a specific beach, with freshly laid clutches being recorded in the order of encounters.

Because determining incubation duration from every clutch would not have been practicable, we collected a representative sample of clutch incubation durations from each of the 6 beaches, and, taking into account the seasonality of nesting, we used the following methodology: every clutch, every second, or every third clutch (depending on the logistic conditions of the 


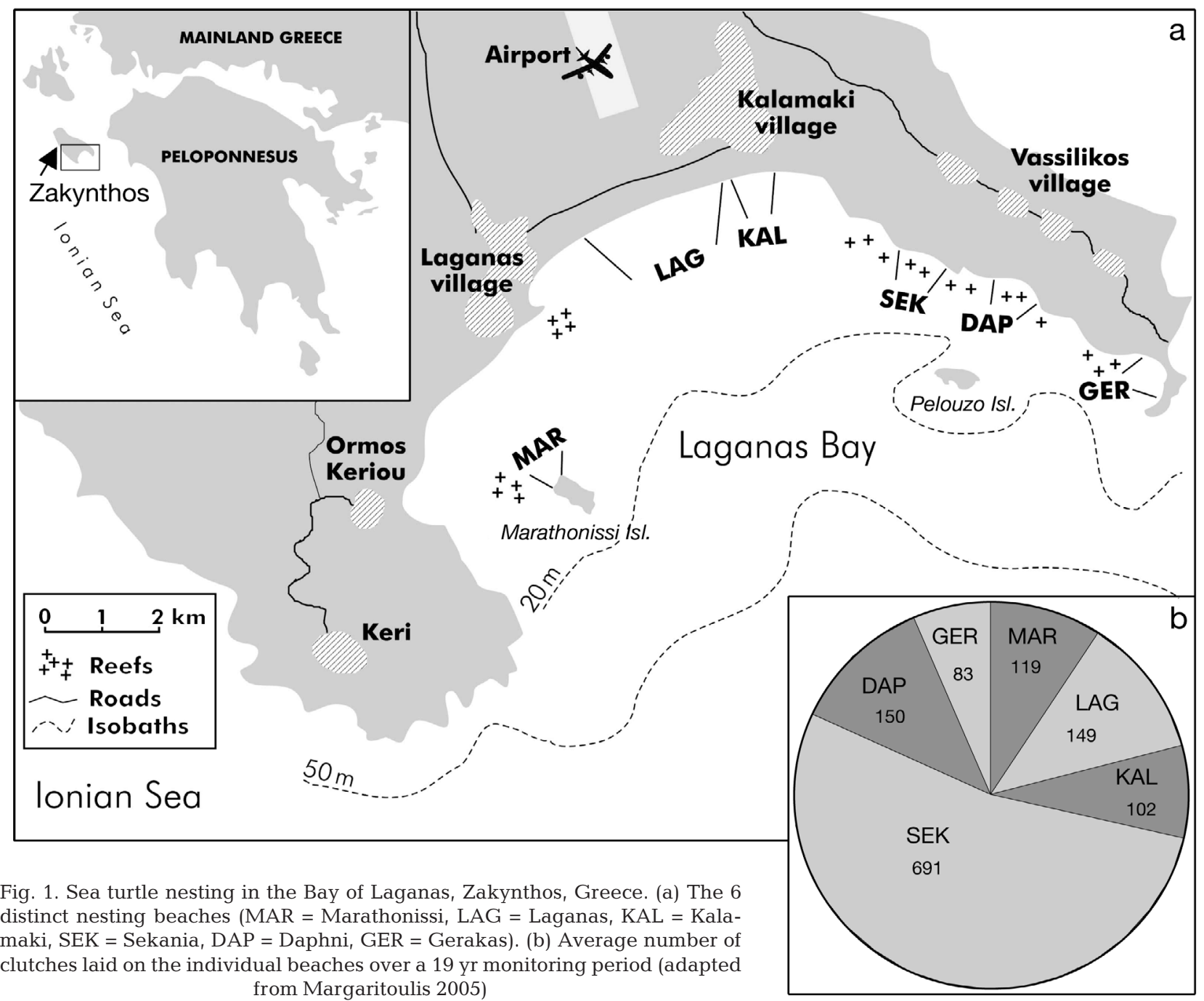

specific beach) encountered on morning patrols was monitored throughout incubation. The morning after such a clutch was laid, its location was triangulated to 2 flanking marker poles set up at the back of the beaches and its distance to the sea measured (sea level fluctuates very little throughout the season in Zakynthos). Each clutch was marked with uniquely numbered stones buried below the sand surface. Clutches from which hatchlings emerged were matched to laid clutches by comparing their location in relation to marker poles and presence of numbered stones. If the identity of a clutch at hatching emergence could not be unequivocally determined, it was excluded from the data set. Likewise, we did not use data on clutches from which first hatchling tracks were likely to have gone undetected because of unfavourable conditions during any of several patrols prior to the first observation of hatchling tracks. We are confident to have greatly reduced errors in determination of first emer- gence date by this approach. Placing a mesh around clutches a few days before minimum incubation duration for the area - as done, for example, by Mrosovsky et al. (1999) — would be a more reliable approach for determining first hatchling emergence, but was logistically not feasible in the study area. We excavated clutches $14 \mathrm{~d}$ after first emergence and categorised their contents (according to Miller 1999), distinguishing the eggs that had developed to over approximately $75 \%$ of incubation length (Miller 1985) from the rest of the material (hatched eggs, earlier stage embryos, as well as eggs with no visible embryos). Eggs developed to over approx. $75 \%$ of incubation length correlate significantly with the amount of clutch metabolic heating in the study area (Zbinden et al. 2006) This parameter was only recorded in 2003.

Spatial variation in incubation durations. We used an analysis of variance (ANOVA) with Tukey-Kramer Honestly Significant Difference (HSD) post-hoc tests 
(program JMP IN ${ }^{\complement}$, version 4.04, SAS Institute) to evaluate the amount of variation in incubation duration that can be attributed to differences amongst beaches as opposed to other factors that may influence this variable. We included in the model the factors beach, laying date, location of the clutch in relation to the sea (distance to sea), the number of eggs that had developed to over $75 \%$ of incubation as well as all pairwise interactions. A second model was run including only those factors which had a significant effect on incubation duration in the original model.

Estimating hatchling sex ratio from incubation duration data. We calculated hatchling sex ratios using the conversion curve relating incubation duration to hatchling sex ratio derived from artificially incubated eggs originating from the nearby (straight-line distance ca. $80 \mathrm{~km}$ ) Peloponnesus rookery (Mrosovsky et al. 2002). The close proximity of the 2 rookeries, the facts that no genetic differentiation can be detected in mitochondrial and nuclear genes (Carreras et al. 2007) and that the pivotal temperature is a conservative characteristic in sea turtles (Bull et al. 1982, Mrosovsky 1988, 1994) makes it very likely that the 2 rookeries do not differ in the relationship between hatchling sex ratio and incubation duration. However, a number of assumptions underlying the use of the conversion curve of Mrosovsky et al. (2002) to infer hatchling sex ratio estimates from field incubation duration data might not be fully met: (1) The relationship between hatchling sex ratio and incubation duration (Mrosovsky et al. 2002) is based on data of just 2 clutches and might thus not reflect average values for the rookery because of interclutch variation in the pivotal temperature (Mrosovsky 1988). (2) Sex determination occurs during the middle third of development (Mrosovsky \& Pieau 1991), whereas the length of incubation duration reflects conditions throughout development, which are affected by the seasonal course of temperature. The occasional occurrence of storms will also make sex ratio estimates inaccurate (Mrosovsky et al. 1999). (3) Moreover, temperature fluctuations around a mean, such as experienced on a daily basis by incubating loggerhead sea turtle clutches (Godley et al. 2001a) can affect hatchling sex ratio (Georges et al. 1994). (4) Furthermore, we corrected the laboratory incubation durations by $4 \mathrm{~d}$, which is the only published estimation of the time gap between hatching from the eggshell and emergence of hatchlings at the sand surface for sea turtles (Godfrey \& Mrosovsky 1997). However, the time between hatching and emergence of clutches in Zakynthos might differ (overall or on specific beaches) from the published $4 \mathrm{~d}$, for example due to differences in sand compactness or depth of the eggs. To account at least in part for these potential shortcomings in determining hatchling sex ratio esti- mates, we calculated 3 different scenarios. First, we assumed no bias in using the conversion curve by Mrosovsky et al. (2002) and thus considered that observed incubation durations of $\leq 55 \mathrm{~d}$ produced only females; $56 \mathrm{~d}$ : $80 \%$ females; 57 d: $50 \%$ of each sex; $58 \mathrm{~d}$ : $10 \%$ females; and $\geq 59 \mathrm{~d}$ : only males. Additionally, we calculated hatchling sex ratios assuming the above conversion overestimates or underestimates the proportion of females produced (assuming the conversion curve is shifted $1 \mathrm{~d}$ of incubation duration to the right or left, respectively). Sex ratio for each beach was estimated by taking into account the proportion of study clutches in each incubation duration class. Finally, we estimated the overall hatchling sex ratio (for the entire nesting area) from beach values accounting for the proportions of clutch numbers on individual beaches to the total number of clutches (our Fig. 1b; Margaritoulis 2005).

Past air temperatures. Due to year-to-year fluctuations in temperature, data from just 2 seasons might not be adequate to estimate hatchling sex ratio from an area. Air temperature has been shown to correlate strongly with sand temperature at sea turtle nest depth in areas with little precipitation (Godley et al. 2001a, Hays et al. 2003, Glen \& Mrosovsky 2004). To evaluate whether our results based on 2 years' data collection are representative of a broader time-scale than the 2 seasons of data collection, we compared summer air temperatures of Zakynthos of 2002 and 2003 to those of 1984 to 2001 (obtained from the Greek Meteorological Network, Athens). Although air temperatures might differ amongst the individual beaches, they are all expected to be affected by the same large-scale meteorological events and hence be very tightly correlated.

\section{RESULTS}

Incubation durations for all beaches ranged from 40 to $85 \mathrm{~d}$ in 2002 and from 41 to $76 \mathrm{~d}$ in 2003, including a total of 217 clutches in 2002 and 328 clutches in 2003 (Fig. 2a,b). The estimated area sex ratio for Zakynthos calculated from incubation durations was female biased, with an estimated $68 \%$ (64 and $73 \%$ assuming the conversion curve over- or underestimates the proportion of females) for 2002 and $75 \%$ (77 and $70 \%$ assuming bias in applying the laboratory-derived conversion curve) of female hatchling production for 2003.

The factor 'beach' as well as the interaction between beach and distance to sea significantly correlated with incubation duration in the 2002 data. The new model which included these 2 factors explained nearly $70 \%$ of the variation in incubation duration (ANOVA, $\left.F_{5,211}=45.49, \mathrm{p}<0.001, \mathrm{R}^{2}=0.69\right)$. There were signifi- 

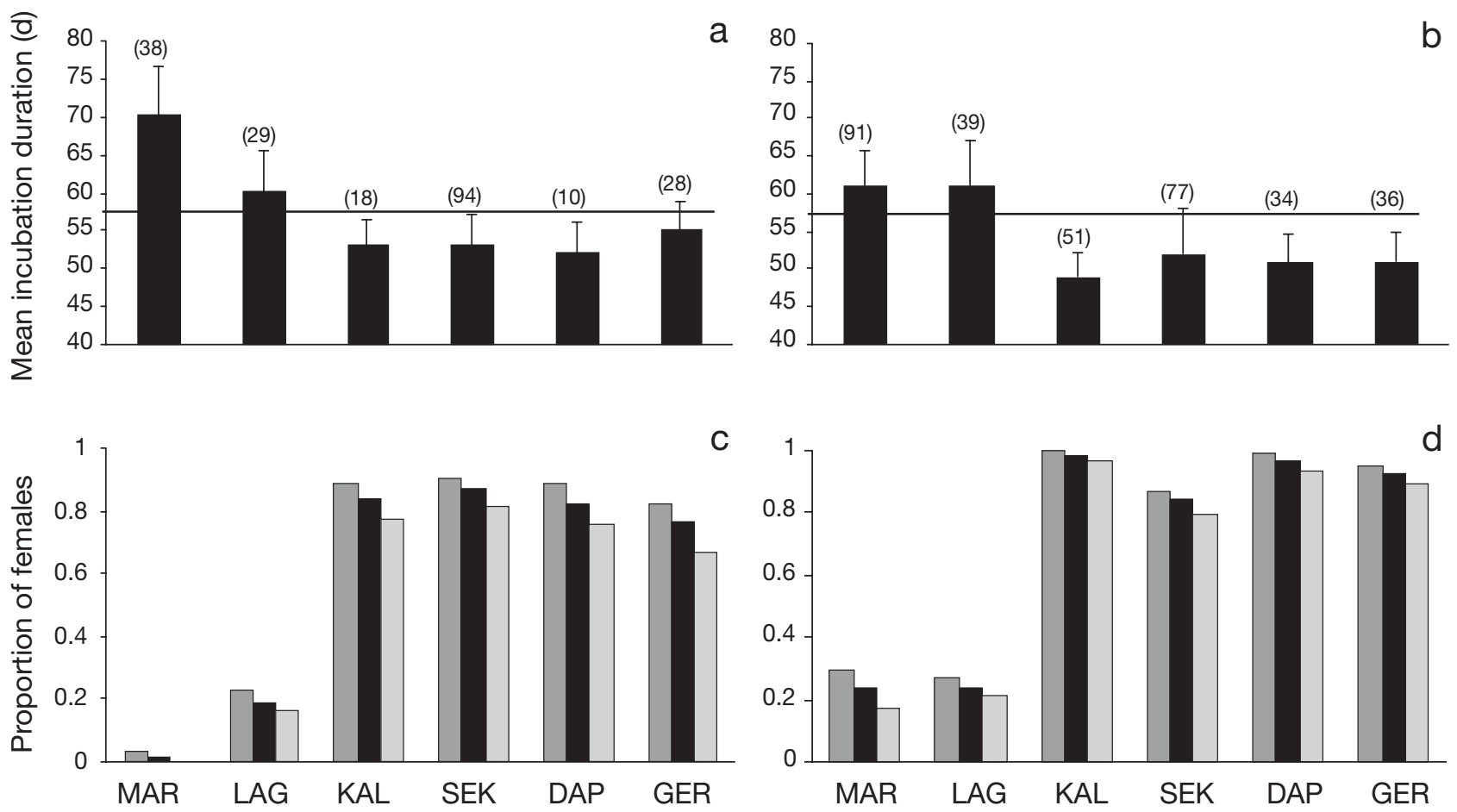

Fig. 2. (a,b) Mean ( \pm SD) incubation duration for (a) 2002 and (b) 2003, sample size (number of clutches) is indicated above each column. The pivotal incubation duration (according to Mrosovsky et al. 2002) is indicated by a horizontal line. (c,d) Derived sex ratio estimates for (c) 2002 and (d) 2003 for individual beaches (see Fig. 1 for abbreviations). Black columns: hatchling sex ratio estimates calculated according to the conversion curve of Mrosovsky et al. (2002); dark grey columns assume a $1 \mathrm{~d}$ longer field incubation duration, resulting in a given hatchling sex ratio; light grey columns assume a $1 \mathrm{~d}$ shorter field incubation duration, resulting in a given hatchling sex ratio. Note that the y-axis in a and b starts at $40 \mathrm{~d}$

cant differences in incubation durations between 2 groups of beaches: Marathonissi and Laganas versus Kalamaki, Sekania, Daphni and Gerakas $(\mathrm{N}=217$, Tukey-Kramer HSD post-hoc test: $\mathrm{q}=2.87, \mathrm{p}<0.05)$. In the 2003 data, for which sample sizes are generally larger and more similar among beaches (Fig. 2 a,b), we found no significant effect of distance of a clutch to the sea or any pairwise interactions on incubation duration. The new model which included beach, laying date and the number of eggs that had developed to over $75 \%$ of incubation explained nearly $60 \%$ of the variation in incubation duration $\left(\right.$ ANOVA, $F_{7,277}=56.66, \mathrm{p}<0.001, \mathrm{R}^{2}$ $=0.59$ ). Laying date and the number of eggs that had developed to over about $75 \%$ of incubation were both significantly negatively correlated with incubation duration. There were significant differences in incubation durations between the beaches Marathonissi and Laganas, which formed one group, and Kalamaki, Sekania, Daphni and Gerakas forming another $(\mathrm{N}=328$, Tukey-Kramer HSD post-hoc test: $\mathrm{q}=2.87, \mathrm{p}<0.05$ ). Within the latter group, incubation durations were statistically different between Kalamaki and Sekania ( $\mathrm{N}=$ 328, Tukey-Kramer HSD post-hoc test: $\mathrm{q}=2.87, \mathrm{p}<$ 0.05). Estimates from both years' data indicate that
Marathonissi and Laganas beach produced a male-biased hatching sex ratio (estimates below $30 \%$ females for both years and all calculated scenarios); the other beaches revealed a female-biased hatchling sex ratio (estimates above $65 \%$ females for both years and all calculated scenarios) (Fig. 2 c,d).

A qualitative comparison of local average air temperatures of July and August (when most clutches are in their thermo-sensitive stage for sex determination) for the years 2002 and 2003 with those of the previous $18 \mathrm{yr}$ confirmed that temperatures during the years of data collection were not unusual compared to the past 2 decades (Fig. 3).

\section{DISCUSSION}

We estimate that hatchling sex ratio of loggerhead sea turtles for Zakynthos was female-biased in 2002 and 2003. Although our inferences using past air temperatures are rather weak because these average values do not provide any information on withinseason temperature variability, they support rather than contradict the notion that the 2 seasons of data 


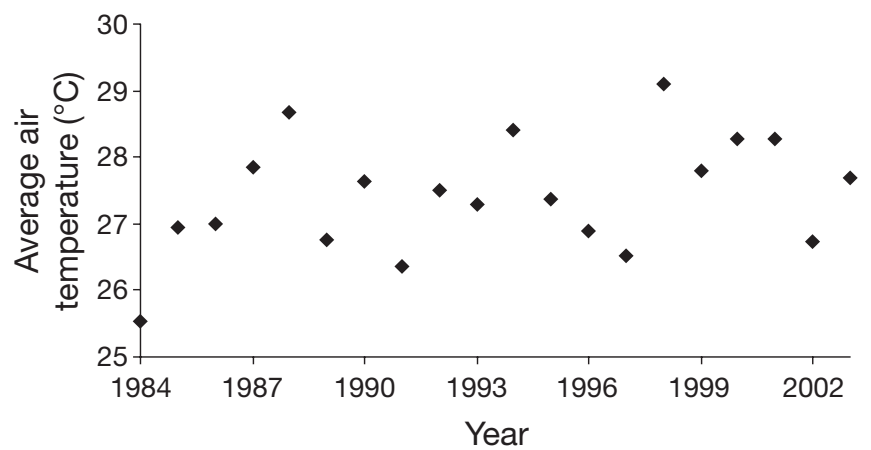

Fig. 3. Average air temperature for July and August from Zakynthos over the past $20 \mathrm{yr}$. The last 2 data points correspond to the 2 seasons of data collection

collection were representative of those during the past 2 decades.

The apparent female bias in hatchlings of Zakynthos fits into the global and Mediterranean-wide female bias in loggerhead sea turtle hatchlings. For the Mediterranean, the most reliable hatchling sex ratio estimates exist from northern Cyprus, where the estimated proportion of female loggerhead sea turtle hatchlings is 89 to $99 \%$ females (Godley et al. 2001a,b). There is also some evidence that the loggerhead sea turtle hatchling sex ratio of Kephalonia (no quantitive estimate given due to low number of clutches included) and Kyparissia Bay (Greece; 70\% female hatchlings estimated) are female-skewed (Houghton \& Hays 2001, Rees \& Margaritoulis 2004). A small (Canbolat 2004) nesting area in Turkey seems to produce 60 to $65 \%$ female hatchlings (Kaska et al. 2006). Information on sex ratios of juveniles and adults likewise indicate that the overall Mediterranean sex ratio is female-biased (Casale et al. 2005, 2006), although the relationship between hatchling, juvenile and adult sex ratios is unknown in sea turtles (see below).

We estimated considerable differences in hatchling sex ratios amongst the beaches of Zakynthos. Spatial variation in hatchling sex ratio is expected over latitudinal scales, and large-scale variation has been reported for loggerhead sea turtles from the eastern USA (Mrosovsky 1988) and Brazil (Marcovaldi et al. 1997, Baptistotte et al. 1999). Small-scale differences in hatchling sex ratio similar to the situation found in Zakynthos, which cannot be attributed to latitudinal differences in air temperature, have previously been reported for the green sea turtle Chelonia mydas rookery of Ascension Island and attributed to variation in sand albedo (Hays et al. 1999, 2001, Godley et al. 2002, Hays et al. 2003). Differences in hatchling sex ratio in small areas have also been documented for freshwater turtles (Vogt \& Bull 1984). Since neither seasonal distribution of clutches, egg chamber depth or clutch sizes differed significantly among the beaches of Zakynthos
(ARCHELON internal reports, unpubl. data), differences in the physical nature of the individual beaches, such as albedo (Hays et al. 2001), beach aspect or inclination - although not quantified in this study - most probably are the determinants of the spatial variation in hatchling sex ratio in Zakynthos. The existence of large spatial variation in incubation conditions within 1 nesting area exemplifies that one cannot readily extrapolate hatchling sex ratio determined from part of a nesting area to the entire area. Likewise, we suggest that spatial variation in hatchling sex ratio production within nesting areas should be carefully explored before selecting areas of conservation priority within sea turtle rookeries.

Our data show that Marathonissi and Laganas beaches produced a male-biased hatchling sex ratio (Marathonissi: 2\% females in 2002 and 23\% females in 2003; Laganas: $19 \%$ females in 2002 and $24 \%$ females in 2003, assuming the underlying conversion leads to unbiased estimates; Fig. 2c,d). So far, the most important beach in terms of clutch numbers (Sekania) is afforded the best protection status. This beach, however, produces a very low proportion of male hatchlings (87 and $84 \%$ females in 2002 and 2003, respectively, assuming the underlying conversion leads to unbiased estimates; Fig. 2c,d). Over the last 3 decades, about half of the nesting habitat of Laganas beach has been destroyed by development and tourism, while hatchlings from Marathonissi beach suffer from disorientation caused by artificial lighting from tourist resorts (J. Zbinden pers. obs.). These beaches that are apparently characterised by comparatively cold incubation temperatures should be adequately protected so as to continue to allow females the opportunity to choose nest sites from a variety of incubation environments. Under scenarios of increasing temperature in the future (although predictions for specific geographic regions are to date uncertain, temperatures in the eastern Mediterranean are thought to increase at roughly the global average; Houghton et al. 2001), where a greater proportion of female hatchlings may be produced, relatively cold beaches may become essential. However, it should be kept in mind that increasing temperatures might not only lead to systematic changes in hatchling sex ratios, but also reduce hatching success when incubation temperatures approach the upper thermal limit for incubation (Godley et al. 2001a, Matsuzawa et al. 2002, Hawkes et al. 2007).

Sea turtle males probably mating every year and females every few years, as well as a promiscuous mating system (Miller 1997), certainly allow sea turtle populations to thrive with a considerable female skew in adult sex ratio. However, more information is needed on the minimum proportion of males necessary for a healthy sea turtle population as well as on the 
relationship between adult and hatchling sex ratio. Differential survival of males and females from hatching to sexual maturity in a long-lived species like the loggerhead sea turtle would result in adult sex ratios being very different from hatchling sex ratios (Girondot et al. 2004). Until more clarity exists on these aspects, it seems prudent to minimise anthropogenic changes of hatchling sex ratios, including degradation of male-producing nesting beaches.

If and how species with temperature-dependent sex determination will be able to avoid extremely skewed hatchling sex ratios or even lethal incubation temperatures is a matter of speculation. Shifts in the temporal distribution of nesting have been proposed (e.g. Weishampel et al. 2004, Hawkes et al. 2007). In a modelling approach on freshwater turtles Chrysemys picta, threshold temperatures evolved more quickly than nest-site choice, but evolutionary response was rather slow for both mechanisms in the light of the predicted climate change (Janzen 1994, Morjan 2003). Kamel \& Mrosovsky (2006) found much higher repeatability for nest-site choice in the hawksbill turtle Eretmochelys imbricata, which suggest a higher evolutionary rate for nest-site choice. Doody et al. (2006) concluded that a lizard species Physignathus lesueurii compensated for climatic differences between breeding areas mainly behaviourally through nest-site choice (level of shading). Sea turtles might likewise react to warming air temperatures spatially by placing their clutches closer to shading vegetation. However, on a larger scale, nest-site fidelity has so far been assumed to prevent spatial adaptation on an ecologically significant time scale. The apparently large thermal differences within a relatively small spatial scale as found in Zakynthos may, however, act as an avenue for females to spatially react to climate change. Namely, although a quantitative analysis has not yet been conducted, individual females frequently alternate between the beaches of Zakynthos for successive nestings within a season (ARCHELON internal reports, unpubl. data). It is therefore conceivable that they could place more clutches on colder nesting beaches as temperatures increase. Continued monitoring of clutch numbers on the individual beaches of Zakynthos will show whether loggerhead sea turtles do indeed take advantage of this situation.

Acknowledgements. We thank the 'MAVA Foundation for the Protection of Nature' for funding. We acknowledge the support of K. Grimanis, H. Strantzalos and A. Rees (ARCHELON). B. Godley as well as A. Aebischer gave valuable inputs on the manucript. ARCHELON volunteers and field assistants A. Bishop, P. Bradshaw, L. Coe, C. Dean, L. Emo, K. Heglund, A. Lazou, A. Reed and M. Sturt were instrumental in data collection. The comments of anonymous reviewers substantially improved the quality of the manuscript.

\section{LITERATURE CITED}

Ackerman RA (1997) The nest environment and the embryonic development of sea turtles. In: Lutz PL, Musick JA (eds) The biology of sea turtles. CRC Press, Boca Raton, FL, p 83-106

Baptistotte C, Scalfoni JT, Mrosovsky N (1999) Male-producing thermal ecology of a southern loggerhead turtle nesting beach in Brazil: implications for conservation. Anim Conserv 2:9-13

Bowen BW, Avise JC, Richardson JI, Meylan AB, Margaritoulis D, Hopkins-Murphy SR (1993) Population structure of loggerhead turtles (Caretta caretta) in the northwestern Atlantic Ocean and Mediterranean Sea. Conserv Biol 7:834-844

Bull JJ, Charnov EL (1989) Enigmatic reptilian sex ratios. Evolution 43:1561-1566

Bull JJ, Vogt RC, McCoy CJ (1982) Sex determining temperatures in turtles: a geographic comparison. Evolution 36:326-332

Canbolat AF (2004) A review of sea turtle nesting activity along the Mediterranean coast of Turkey. Biol Conserv 116:81-91

Carreras C, Pascual M, Cardona L, Aguilar A and others (2007) The genetic structure of the loggerhead sea turtle (Caretta caretta) in the Mediterranean as revealed by nuclear and mitochondrial DNA and its conservation implications. Conserv Genet 8:761-775

Casale P, Freggi D, Basso R, Argano R (2005) Size at male maturity, sexing methods and adult sex ratio in loggerhead turtles (Caretta caretta) from Italian waters investigated through tail measurements. Herpetol J 15: 145-148

Casale P, Lazar B, Pont S, Tomás J and others (2006) Sex ratio of juvenile loggerhead sea turtles Caretta caretta in the Mediterranean Sea. Mar Ecol Prog Ser 324:281-285

Caughley G, Gunn A (1996) Conservation biology in theory and practice. Blackwell Science, Cambridge

Doody JS, Guarino E, Georges A, Corey B, Murray G, Ewert M (2006) Nest site choice compensates for climate effects on sex ratios in a lizard with environmental sex determination. Evol Ecol 20:307-330

Fisher RA (1930) The genetical theory of natural selection. Clarendon Press, Oxford

Freedberg S, Wade MJ (2001) Cultural inheritance as a mechanism for population sex-ratio bias in reptiles. Evolution 55:1049-1055

Georges A, Limpus C, Stoutjesdijk R (1994) Hatchling sex in the marine turtle Caretta caretta is determined by proportion of development at a temperature, not daily duration of exposure. J Exp Zool 270:432-444

Gerosa G, Casale P (1999) Interaction of marine turtles with fisheries in the Mediterranean. United Nations Environment Programme (MAP), RAC/SPA, Tunis

Girondot M, Fouillet H, Pieau C (1998) Feminizing turtle embryos as a conservation tool. Conserv Biol 12:353-362

Girondot M, Delmas V, Rivalal P, Courchamp F, PrévotJulliard AC, Godfrey MH (2004) Implication of temperature-dependent sex determination for population dynamics. In: Valenzuela N, Bull JJ (eds) Temperaturedependent sex determination. Smithsonian Books, Washington, DC, p 48-155

Glen F, Mrosovsky N (2004) Antigua revisited: the impact of climate change on sand and nest temperatures at a hawksbill turtle (Eretmochelys imbricata) nesting beach. Global Change Biol 10:2036-2045

Godfrey MH, Mrosovsky N (1997) Estimating the time between hatching of sea turtles and their emergence from the nest. Chelonian Conserv Biol 2:581-585 
Godley BJ, Broderick AC, Downie JR, Glen F and others (2001a) Thermal conditions in nests of loggerhead turtles: further evidence suggesting female skewed sex ratios of hatchling production in the Mediterranean. J Exp Mar Biol Ecol 263:45-63

Godley BJ, Broderick AC, Mrosovsky N (2001b) Estimating hatchling sex ratios of loggerhead turtles in Cyprus from incubation durations. Mar Ecol Prog Ser 210:195-201

Godley BJ, Broderick AC, Glen F, Hays GC (2002) Temperature-dependent sex determination of Ascension Island green turtles. Mar Ecol Prog Ser 226:115-124

Hawkes LA, Broderick AC, Godfrey MH, Godley BJ (2007) Investigating the potential impacts of climate change on a marine turtle population. Global Change Biol 13:923-932

Hays GC, Godley BJ, Broderick AC (1999) Long-term thermal conditions on the nesting beaches of green turtles on Ascension Island. Mar Ecol Prog Ser 185:297-299

Hays GC, Ashworth JS, Barnsley MJ, Broderick AC and others (2001) The importance of sand albedo for the thermal conditions on sea turtle nesting beaches. Oikos 93:87-94

Hays GC, Broderick AC, Glen F, Godley BJ (2003) Climate change and sea turtles: 150-year reconstruction of incubation temperatures at a major marine turtle rookery. Global Change Biol 9:642-646

Houghton JDR, Hays GC (2001) Asynchronous emergence by loggerhead turtle (Caretta caretta) hatchlings. Naturwissenschaften 88:133-136

Houghton JT, Ding Y, Griggs DJ, Noguer M Linden PJvd, Xiasu D (2001) IPCC Third assessment report: climate change. Cambridge University Press, Cambridge

Hutton JM (1987) Incubation temperatures, sex ratios and sex determination in a population of Nile crocodiles (Crocodylus niloticus). J Zool (Lond) 11:143-155

Janzen FJ (1994) Climate change and temperature-dependent sex determination in reptiles. Proc Natl Acad Sci USA 91:7487-7490

Kamel SJ, Mrosovsky N (2006) Inter-seasonal maintenance of individual nest site preferences in hawksbill sea turtles. Ecology 87:2947-2952

Kaska Y, Ilgaz C, Özdemir A, Baskale E, Türkozan O, Baran I, Stachowitsch M (2006) Sex ratio estimations of loggerhead sea turtle hatchlings by histological examination and nest temperatures at Fethiye beach, Turkey. Naturwissenschaften 93:338-343

Laurent L, Lescure J, Excoffier L, Bowen B and others (1993) Etude génétique des relations entre les populations Méditerranéenne et Atlantique d'une tortue marine (Caretta caretta) à l'aide d'un marqueur mitochondrial. C R Acad Sci Ser III Life Sci 316:1233-1239

Lewison RL, Freeman SA, Crowder LB (2004) Quantifiying the effects of fisheries on threatened species: the impact of pelagic longlines on loggerhead and leatherback sea turtles. Ecol Lett 7:221-231

Marcovaldi MA, Godfrey MH, Mrosovsky N (1997) Estimating sex ratios of loggerhead turtles in Brazil from pivotal incubation durations. Can J Zool 75:755-770

Margaritoulis D (2005) Nesting activity and reproductive output of loggerhead sea turtles, Caretta caretta, over 19

Editorial responsibility: Mike Thompson, Sydney, Australia seasons (1984-2002) at Laganas Bay, Zakynthos, Greece: The largest rookery in the Mediterranean. Chelonian Conserv Biol 4:916-929

Margaritoulis D, Argano R, Baran I, Bentivegna F and others (2003) Loggerhead turtles in the Mediterranean Sea: Present knowledge and conservation perspectives. In: Bolten AB, Witherington BE (eds) Loggerhead Sea Turtles. Smithsonian Institution, Washington, DC, p 175-198

Matsuzawa Y, Sato K, Sakamoto W, Bjorndal KA (2002) Seasonal fluctuations in sand temperature: effects on the incubation period and mortality of loggerhead sea turtle (Caretta caretta) pre-emergent hatchlings in Minabe, Japan. Mar Biol 140:639-646

Miller JD (1985) Embryology of marine turtles. In: Gans C, Billett F, Maderson PFA (eds) Biology of the reptilia, development A. John Wiley \& Sons, New York, p 269-328

Miller JD (1997) Reproduction in sea turtles. In: Lutz PL, Musick JA (eds) The biology of sea turtles, Vol I. CRC Press, Boca Raton, FL, p 51-81

Miller JD (1999) Determining clutch size and hatching success. In: Eckert KL, Bjorndal KA, Abreu-Grobois FA, Donnelly $M$ (eds) Research and management techniques for the conservation of sea turtles. IUCN/SSC Marine Turtle Specialist Group, Publication No. 4, p 124-129

Morjan CL (2003) How rapidly can maternal bahavior affecting primary sex ratio evolve in a reptile with environmental sex determination? Am Nat 162:205-219

Mrosovsky N (1988) Pivotal temperature for loggerhead turtles (Caretta caretta) from northern and southern nesting beaches. Can J Zool 66:661-669

Mrosovsky N (1994) Sex ratios of sea turtles. J Exp Zool 270:16-27

Mrosovsky N, Pieau C (1991) Transitional range of temperature, pivotal temperatures and thermosensitive stages for sex determination in reptiles. Amphib-reptilia 12:169-179

Mrosovsky N, Baptistotte C, Godfrey MH (1999) Validation of incubation duration as an index of the sex ratio of hatchling sea turtles. Can J Zool 77:831-835

Mrosovsky N, Kamel S, Rees AF, Margaritoulis D (2002) Pivotal temperature for loggerhead turtles (Caretta caretta) from Kyparissia Bay, Greece. Can J Zool 80: 2118-2124

Rees AF, Margaritoulis D (2004) Beach temperatures, incubation durations and estimated hatchling sex ratio for loggerhead sea turtle nests in southern Kyparissia Bay, Greece. Testudo 6:23-36

Vogt RC, Bull JJ (1984) Ecology of hatchling sex ratio in map turtles. Ecology 65:582-587

Weishampel JF, Bagley DA, Ehrhart LM (2004) Earlier nesting by loggerhead sea turtles following sea surface warming. Global Change Biol 10:1424-1427

Wibbels T (2003) Critical approaches to sex determination in sea turtles. In: Lutz PL, Musick JA, Wyneken J (eds) The biology of sea turtles, Vol II. CRC Press, Boca Raton, FL, p 103-134

Zbinden JA, Margaritoulis D, Arlettaz R (2006) Metabolic heating in Mediterranean loggerhead sea turtle clutches. J Exp Mar Biol Ecol 334:151-157

Submitted: May 14, 2007; Accepted: September 26, 2007 Proofs received from author(s): November 1, 2007 